\title{
Impact of Female Financial Inclusion on Economic Development: Evidence from an Emerging Economy
}

\author{
Sadia Noor Khan ${ }^{1 *}$ Md. Golam Ramij ${ }^{2}$ \\ 1 An Assistant Professor at the Department of Banking and Insurance, University of Dhaka \\ 2 Lecturer at the Department of Banking and Insurance, University of Dhaka
}

\begin{abstract}
This study aims to investigate the effects of female financial inclusion on the economic development of Bangladesh. Female financial inclusion indicates the access of women to financial services. Female financial inclusion by ensuring participation of women in the financial system can ensure both economic and social wellbeing as this helps to decrease inequality and enables higher economic development. The empirical analysis of this research has been conducted through data obtained from banks of Bangladesh. The results suggest that, accounts of women in bank and savings of women with a bank have high impact in driving higher economic development of Bangladesh. However, the results indicate that borrowings of women from a bank is not triggering the higher inclusive economic development of Bangladesh.
\end{abstract}

Keywords: Female financial inclusion, Economic development

DOI: $10.7176 / \mathrm{EJBM} / 13-24-07$

Publication date: December $31^{\text {st }} 2021$

\section{Introduction}

Financial inclusion can be defined as access to formal financial services by unbanked people or the proportion of the business entities and individuals who benefit from these services (Kim, 2016). Nowadays, financial inclusion has gained the special attention of the government, researchers, and society in general because of its ability to include a wide range of people to provide standard financial services at a reasonable price. There is a huge gap in access to finance worldwide, and only financial inclusion can address the issue. By promoting financial inclusion, we can address inequalities in access to finance; thereby, it will help to reduce poverty and ensure economic growth (Demirguc-Kunt, Klapper, and Singer, 2013). In Bangladesh, women have less accessibility to having a bank account. Only 36 percent of women have a formal bank account, whereas male account holders possess 65 percent (Global Findex Database, 2017).

In Bangladesh, there has been a significant acceleration of girls' participation in secondary school enrollment from $39 \%$ in 1998 to $67 \%$. Nevertheless, there was a 42\% dropout from secondary school level in 2017 (World Bank, 2019). Thus fewer women are as literate as men. Banks and financial institutions found literacy as a major barrier for women to have banking services. As a result, they cannot read and write properly, which is a requirement for bank documentation (Wahid, 2020). A lower literacy rate lowers female labor force participation than men. To achieve the SDG goals by 2030, Bangladesh needs to focus on several goals of SDGs. If Bangladesh wants to meet up the requirements of the goal one, four and five, increasing access and quality of services, equal rights to economic resources, including financial services, enabling technology to promote the empowerment of women and ensuring financial literacy and numeracy is a must to achieve those goals (The World Bank, 2019).

Due to cultural, physical, and structural barriers, women have limited access to economic opportunities. As a result, they suffer the brunt of poverty (Lagarde,2014). Access to finance has opened the door to economic independence through empowerment. Women constitute $51 \%$ of the population in Bangladesh (World Economic Forum, 2019), and their engagement is crucial for sustained growth and development of the economy. Financial inclusion brings them one step closer to this goal. In Bangladesh the participation of women in the labor force has been gradually expanding over the last decade, from around 37 percent in 2011 to 44 percent in 2018 (The World Bank, 2020). In 201637.7 percent of the women accounted for "self-employment jobs" working for businesses venture from living their household (The World Bank, 2020). Ninety-four thousand eight hundred women are working in microenterprises in Bangladesh (UNCDF-SHIFT, 2018).

Women's economic empowerment is the only way to boosts productivity, achieving economic diversification, and ensure income equality. Promoting female empowerment in OECD countries to match Sweden's could increase GDP by more than USD 6 trillion (IMF, 2018). It is found that the gender gap has an opportunity cost of about 15 percent of the GDP (Cuberes et al.,2016). If women are given access to financial services like having a bank account, credit card, and digital payments can enhance their earning potential. It will enable them to spend in healthcare, education, and business. The internet and access to use mobile phones embark a new opportunity for financial inclusion that increases employment opportunities and economic growth of a country. Fifty-six percent of all unbanked adults are women in countries like China, India, and the situation is still higher in Bangladesh and Colombia (Global Findex Database,2017). Bangladesh has shown remarkable progress in the last twenty years in improving the quality of life of women and girls. Maternal mortality rates are declining, and there 
is greater gender parity in school enrollment.

It is essential to promote gender equality and advance women's status in achieving the 5th goal of sustainable development goal( SDG). According to the report of gender gap index of world economic forum in 2020, Bangladesh ranks 50th position out of 153 countries, demonstrating significant progress compared to 86th position recorded in 2012 (World Economic Forum, 2019). In other areas, especially in women's economic participation and opportunity, Bangladesh ranks 140, and in education, it stood 120th position. Formal access to finance is one of the greatest impediments for women entrepreneurs especially engaged in the cottage and micro businesses. Women are also considered high-risk borrowers by institutions due to the lack of their formal credit history (GIIN, 2019). There is an assumption that women-produced and marketed products are considered niche despite having a huge market opportunity. Financial institutions will struggle to develop tailored and appropriate financial services for women in Bangladesh without accurate data on women's workplace, business, and economic participation.

Access to financial services based on usage can be termed in two levels- at the household and individual level. A study conducted in Bangladesh found that around 53 percent of the households have access to formal financial services in terms of access to deposits and mobile banking. Among them, 32 percent have access to deposits, and 27 percent have access to mobile banking. Mobile banking has captured a 10.81 percent net effect (Khalily et al., 2015). it has been found that only 9 percent of the households had access to credit, and around 13 percent had access to the insurance market. This penetration is low because of high charges, the need for collateral, lack of financial security, and the formal market for financial products is not conveniently accessible.

Bangladesh is a role model for pioneering financial inclusion and particularly for microcredit programs for women. Women tend to save their money in microfinance institutions though 7 percent of women tend to save informally. Their main purpose of savings is usually to meet up family emergencies, cash flow, and household needs. They also took a loan to pay off the health services. Women's wise use of money brings confidence in financial institutions and considers women as less risky customers. Despite $89 \%$ of women being knowledgeable about mobile money, only 55 percent of women in Bangladesh own a mobile device, and only 27 percent use mobile money services (The GSMA, 2019). Bangladesh is committed to becoming a digital economy, and there is a huge opportunity to bring more women under financial inclusion by converting their mobile ownership into mobile financial service users.

An extensive gender gap is observed in financial literacy and numeracy, access to finance, financial services, etc. Survey reveals that women always remain financially deprived compared to men. The highest gender gap was found in registered mobile financial services users with 58 percent, and in the case of a bank account, it was 33 percent (Ahmed, 2020). CSAs help promote financial literacy and positive financial practices in Bangladesh through pre-disbursement orientations and financial education training. These empower clients to understand their financial options better and manage their finances responsibly (Wachira, 2019).

In this situation, MFS (Mobile Financial Services) shows a great potential to narrow this gap. Through MFS, it can reach a greater number of people, including women living in rural areas and women working in readymade garment sectors (RMG). The RMG sectors employ around 3.4 million women and out of which 81 percent are still unbanked. Digitalization of the payment system to these working women would enable them to bring under financial inclusion. In this case, using the facility of MFS, they will be able to conduct their financial activities like receiving salaries, sending money to their families, and savings for the future. The BGMEA has shown interest in the adoption of digital payment systems in their 4,500 member factories. The IFC advisory has replicated this model in Haiti and Cambodia (Global Findex Database, 2017).

Financial inclusion has become a buzzword in Bangladesh. The sole responsibility to implement the financial inclusion lies with the Bangladesh Bank, the central bank of Bangladesh. The central bank has adopted many initiatives to increase the financial inclusion penetration (Khalily and Khaleque, 2011). The initiatives are targeted credit programs for women, opening branch of banks in rural areas by commercial banks, promoting savings habits among children through school banking, requiring bank account for other government cash transfers, and encouraging financial innovations like Mobile banking, Internet Agent banking, etc. Apart from this, the Microcredit Regulatory Authority (MRA) has continuously promoted and expanded financial services to financial inclusion and poverty alleviation (Khalily and Khaleque, 2013).

Over $13 \%$ of the adult population has access to mobile banking, and it is expected that the use of this service is comparatively higher in urban areas and non-poor households. The intensity of financial inclusion has been increased to $26 \%$, of which the contribution of mobile banking was 9 percent. Mobile banking includes $17 \%$ of the adult population under financial inclusion. Khalili and Meyar (2015) identified that female individuals are greatly excluded from financial markets but significantly in microfinance institutions. In the microfinance industry, around $90 \%$ of customers are female.

In the above discussion, we have learned about the economic contribution of women in different sectors that are accounted for and some other contributions that are not recognized. Financial inclusion plays a crucial role in recognizing women's economic contribution in Bangladesh. In this context, to the best of our knowledge, there 
has been no prior study. This study aims to explore whether the greater financial inclusion of women has a considerable impact on the economic growth of Bangladesh.

\section{Review of Literature}

Financial inclusion can be defined as access to and use of quality, sustainable, and secured financial services by the people of a country. It includes a vast range of financial products and services provided by banks and other financial institutions. However, the main products are bank accounts, credit cards, ATM services, loans, and other forms of credit. A society is called financially inclusive when most citizens have access to formal financial products and services. Through financial inclusion, the goal of socio-economic equality can be achieved by reducing poverty and promoting financial services and infrastructure development (Shrivastava and Satam, 2015). Women's empowerment can be defined as bringing economic change to increase their capacity for themselves. These economic changes work as the crucial contributing factors to achieving equity between men and women (ICRW, 2010). Lack of education, lack of proper training social immobility often hinders them from responding to these opportunities. Women in Bangladesh also ensure their household food security and their domestic work by rearing livestock and growing vegetables and fruits. Farm activities like selection of seed to harvesting, storing crops are managed by women instead of men workers (InM, 2015)

The income of the female is playing a vital role, and it is increasing at a significant rate in rural households due to increasing economic pressures. Gender roles are becoming flexible and enable women to engage in traditional work previously regarded as men's jobs. Social norms and cultural trends are changing due to demand for improving the financial condition and food crisis (Shirin, 1995). This motivation increases the speed of achieving sustainable development goals.

Women's empowerment depends on enough control over resources, individual capacity, self-confidence, selfefficacy, and the changing conventional ideology (Sen and Batliwala, 2000). The issues that affect women's empowerment in the Indian subcontinent include the patriarchal value system, social attitudes and practices, poor level of political participation, lack of legal awareness, and poor economic status (Mohanty, 1995). Women empowerment in Bangladesh is linked to women's economic advancement and self-dependency (Rahman, 2013).

Female participation in business activities is considered one of the fundamental indicators of economic growth. Women represent half of the labor force aged 15-49 in Bangladesh, contributing to entrepreneurial initiatives and promoting access to finance, which is a remarkable achievement for the country's socio-economic development. According to the Bangladesh Labor Force Survey 2013, female participation was only 32.9\%, whereas their male counterparts were $81.7 \%$. Women accounted for only $7.2 \%$ of cottage small and medium enterprises (CSME), which is insignificant. There are several reasons for low participation because of the several cultural and economic barriers. Nevertheless, the greatest barrier is access to finance (AFI, 2017). The present government has crafted a new financial inclusion policy to improve financial inclusion for women to address the issue.

The conventional economic growth measures that GDP measures do not consider the multidimensional and diverse range of activities that inform the interface between human beings and the economy (Khatun et al., 2015). A major part of economic activity undertaken by women is not accounted for in traditional GDP measurement. Such as household chores, helping in agriculture, family farm, care is some of the examples. It results in undermining the women's role in economic growth. Cross-country analysis reveals that if we account for the contribution of the women, the real scenario of GDP would be higher than what is normally expressed. In Bangladesh and many other countries, this exclusion is a major limitation in the national accounting system. This underestimation of women's contribution to GDP transmit a wrong message to the policymakers whose allocative and distributional decisions are then influenced by this (Khatun et al., 2015)

The seventh five-year plan (7th FYP 2015-20201) is designed for women empowerment and gender equality, adopting four goals. One of the most crucial goals is increasing economic benefits for women through access to financial services. Its targets are increasing female participation in the non-agriculture sector, mainly in MSMEs, from $25 \%$ to $50 \%$ by 2015 . The achievement was $32 \%$ which is still below the target level. The new 7 th FYP did not set any new goal but emphasized preferential access to credit and training programs. The government has established a foundation in promoting the SME sector in Bangladesh, aiming to develop business skills for women. With the help of the central bank, the SME foundation is working on bringing women entrepreneurs into the mainstream through capacity-building initiatives, encouraging banks to finance women entrepreneurs, SME product and service fair for women, organizing conferences, and other skill-building initiatives. Bangladesh Bureau of Statistics (BBS) has created a comprehensive information repository for the SME sector. The census will focus on counting women entrepreneurs in manufacturing SMEs (AFI, 2017).

Through the development and expansion of micro, small and medium enterprises, MSMEs mass financial inclusion of women can be achieved. Bangladesh bank is the apex body for banks and other financial institutions, regulating 61 banks and 33 financial institutions. All the banks are now financing in MSMEs as they have seen a significant contribution in the economic growth of this sectors (UNCDF, 2006). The Bangladesh bank has set a 
weight of 5\% in CAMELS rating for MSME financing, which ranks the financial health of a financial institution. When BB (Bangladesh Bank) rates bank, it highlights the bank's performance in women-led-MSMEs. Nowadays, $15 \%$ of Bangladesh Bank's refinance funds for the MSME sector have been allocated for women entrepreneurs (AFI, 2017).

Bangladesh Bank has taken some initiatives that will ensure higher financial inclusion and accept the contribution of women in economic growth. The remarkable initiatives are as follows: 15 percent of refinancing funds are allocated for women, the favorable interest rate for credit at a bank rate plus 5\%, sanction of loans without collateral up to tk. 2.5 million but against a personal guarantee, group-based lending to women starting from Tk. For micro-entrepreneurs, fifty thousand or above, opening a women entrepreneurs development unit in BBs head office and branch office. All commercial banks are also advised to do so. Banks are also advised to find promising women entrepreneurs and promote them by providing credit facilities and training to the selected entrepreneurs.

In Bangladesh, banks and financial institutions together financed USD 231 million for 13,233 women-led MSMEs in 2010. The amount of money became almost doubled in 2015, which was USD 543 to 188233 women entrepreneurs. It indicates that the policy initiative of BB boosted financial inclusion for women in Bangladesh. In 2015 the number of MFI clients accounted for 26.21 million, of which 23.78 million were women. In the same year, 22.36 million entrepreneurs took loans from MFIs, and 20.30 million were women entrepreneurs. It has been observed that more than $90 \%$ of MFI clients and borrowers were female, and half were MSME clients. (BB, 2016).

Microfinance institutions (MFI) play a crucial role in expanding the financial inclusion of women of all ages in Bangladesh and greatly recognize women's economic contribution. MFIs efficiently enable the mobilization of resources and offering financial services to the larger population, poor, non-poor, rural, and urban. It is worth noting that access to formal financial services consists of savings, credit, insurance, and mobile bank account, while access to microfinance includes savings and credit services (InM, 2015).

In Bangladesh, $89 \%$ of women are aware of mobile money, only $55 \%$ of women in Bangladesh own mobile, and only $27 \%$ have used mobile money services (The GSMA, 2019). The growth of e-commerce also influenced women to come under financial services and creating employment opportunities. The growth of technology works as a catalyst for women's financial inclusion and contributes to the country's economic growth. E-commerce grew 127 percent in urban areas and 167 percent in rural areas. This greater expansion was possible by increasing internet and social media penetration (CGAP, 2019). Women dominate e-commerce as it enables them to be entrepreneurs and earn money from home by selling their homemade goods (Islam, 2018).

The OECD (Organization for Economic Co-operation and Development) has defined financial literacy as the combination of an understanding financial services and theories by the users and investors on the ability to feel financial risks and opportunities so that they can independently make financial choices, know where to go for advice to improve their financial welfare (Miller et al., 2009). Those with financial literacy can make household budgets, allocate income, plan for savings, and formulate an efficient investment plan (Greenspan, 2002). Khalili and Miah (2015) conducted a study based on the financial literacy of the people of Bangladesh based on the knowledge related to banks, inflation, and mathematics. They found that only 38.5 percent of the participants obtained passing marks.

The Centre of Policy Dialogue (CPD) and Manusher Jonno Foundation (MJF) has implicated System National Account (SNA) to account for the women's contribution to the GDP. At first, they have shown that female family members spend three times more hours in non-SNA activities than their male counterparts. Secondly, they have estimated the value of women's non-SNA activities, 76.8 percent of Bangladesh's GDP in FY13-14 based on the replacement cost method, and 87.2 percent of gross domestic product based on willingness to accept method. The interesting findings were that the figure was 2.9 times higher than the women's income from paid work (Khatun et al., 2015).

According to the ILO (2006), worldwide, women constitute one-third of the workforce in terms of the informal sector. In Bangladesh, only $3.25 \%$ of women work in the public sector, and $8.25 \%$ work in the private sector, and the remaining $89.5 \%$ percent are working in the informal sector (International Labor Office, 2006).

In Bangladesh, unpaid works done by women do not count in either GDP or GNI (Gross National Income). However, several activities like domestic labor and caregiving are valued and create social capital, which could be added to GDP if valued appropriately. If we do not value the unpaid works of women, we are selfishly undermining their economic contribution. It also reduces their social status and bargaining power in the family decision-making. Now unpaid works have become a part of unequal power relations between men and women (Thompson \& Walker, 1995)

Since the 1970's women comprise half of the country's population, and they have played a pivotal role in Bangladesh's economy and political regime. Now women are considered safe borrowers compared to men because they are reliable customers in terms of repayment. Especially women's contribution in agriculture significantly alleviated poverty in rural areas using the benefits of microcredit program. The involvement of women in the readymade export-oriented garment has brought a significant change in financial inclusion and their contribution to economic growth. The Food for Education program was piloted in 1980, which helped reduce the gender gap 
in education at the primary and secondary school levels (Kabeer, 2013).

In Bangladesh, access to finance and other forces has increased women's labor force participation than that of men. In 2010 the female labor force participation was 4.5 times higher than in 1983-84. In 1974 the labor participation of women aged ten and above was only four percent. Interestingly, there was no significant change in the participation of men in the labor force at that particular time. It was 80.4 percent in 1974 and $82.5 \%$ in 2010 . These data demonstrate the increased participation of women in conventional economic activities in addition to 'unrecognized' households (BBS, 2013).

Three million women are performing their job in the readymade garment sector. Women are greatly involved in small and medium enterprises. However, there is a lack of access to finance. By increasing women's empowerment, USAID promotes economic growth in Bangladesh. USAID efforts helped women obtain loans for farming mechanization service businesses from different sources like government, private banks, and microfinance institutions. Despite the initiatives, some rural women took loans at a very high-interest rate from informal money lenders. USAID has established community groups that enable women to save money and take loans to overcome this situation. As a result, more women now have access to low-interest funds that help them be more resilient and independent (Haque, 2021). Considering the fact that women of Bangladesh has less access to financial services compared to men and the access of women to financial services is essential to ensure financial inclusion, we propose the following hypothesis:

H1. There is a positive relationship between female financial inclusion and the economic development of Bangladesh.

\section{Research Objectives:}

The researchers are particularly interested to explore and gain insights of the following aspect-

* To investigate the effects of female financial inclusion on the inclusive economic development of Bangladesh.

\section{Methodology}

4.1 Sample and Data Collection

This study undertakes quantitative study based on the relevant literature necessary to investigate the effects of female financial inclusion on the inclusion economic development of Bangladesh. This is an exploratory study where the data collection method is depending on secondary data. Data collected from secondary sources have been processed and sata was being coded, scrutinized and categorized grounded on the queries of the research. Data of GDP, savings of female and borrowings of female have been used in the form of million taka for analysis. This study covers a period of ten years from 2011 to 2020. The study concentrates mostly on data collected from Bangladesh Bank and Bureau of Statistics.

\subsection{Measuring variables}

\subsubsection{Dependent Variable}

In this study, the dependent variable is economic development (ECO_ DVLPMNT) which is defined as the logarithm of GDP per capita of Bangladesh. There is a significant association between the economic development of a country and an increase in income, savings, investment and consumption of that particular country (L. CabezaGarcía et al).

4.2.2 Explanatory Variables

The explanatory variable of our study is female financial inclusion which can be measured through different dimensions. The World Bank has also provided a set of Global Financial Inclusion (Global Findex) indicators which is comprised of savings and borrowings. In our study, we have selected three different measures to proxy financial inclusion. These three measures are bank accounts, borrowings and savings. 
Table 1. Variable definitions

This table describes the details of the variables in this study including dependent variable and explanatory variables. In this study we have employed one dependent variable and three explanatory variables

\begin{tabular}{|l|l|l|}
\hline Variable Name & Symbols & Definition \\
\hline Panel A: Dependent Variable & ECO_DVLPMNT & GDP per capita of Bangladesh \\
\hline Economic Development & ACCOUNT & $\begin{array}{l}\text { Account of female with a scheduled bank of } \\
\text { Bangladesh. }\end{array}$ \\
\hline Panel B: Independent Variables & Access to Bank Account & $\begin{array}{l}\text { Financing taken by female from a scheduled bank } \\
\text { of Bangladesh. }\end{array}$ \\
\hline Borrowing from Bank & $\begin{array}{l}\text { Deposits maintained by female with a scheduled } \\
\text { bank of Bangladesh. }\end{array}$ \\
\hline Savings with Bank & SAVINGS & Bang \\
\hline
\end{tabular}

ACCOUNT: The first variable of our study is access to a bank account, ACCOUNT (L. Cabeza-García et al). Here, we have measured the number of females over 18 years having an account at a formal financial institution in Bangladesh.

BORROWINGS: The second explanatory variable of our study is BORROWINGS which can be defined as borrowings of female from a scheduled bank of Bangladesh (Dutt \& Sharma, 2016; Ghosh \& Vinod, 2017). This is basically the loans provided by scheduled banks of Bangladesh to female.

SAVINGS: The third explanatory variable of our study is SAVINGS which can be defined as the amount of savings of female with a scheduled bank of Bangladesh. This is basically the deposits that female of Bangladesh maintains with banks of Bangladesh.

\section{Data Analysis}

To test the hypothesis and to investigate the impact of female financial inclusion on economic development, we run the following regression model which can be specified as follows-

Model for testing hypotheses-

$$
\text { ECO_DVLPMNT }=\alpha+\beta 1 \text { ACCOUNT }+\beta 2 \text { BORROWINGS }+\beta 3 \text { SAVINGS }+\mu_{i}
$$

where $\alpha$ is the constant and $\varepsilon$ is the error term.

\section{Empirical Analysis and Results}

6.1 Descriptive Statistics

Table 2 represents the summary of the descriptive statistics of all the variables used in this study. The summary indicates that, mean level of economic development is 17446 million taka. The mean of the number of accounts of the female is 30502039. Also, the results indicate that, average savings of the female is 4447717 million taka and average borrowings of the female of Bangladesh from the banking sector of Bangladesh is 186458 million taka.

Table 2. Summary Statistics

This table represents the descriptive statistics of this study. Here ECO DVLPMNT is the dependent variable. On the other hand, ACCOUNT, BORROWINGS, SAVINGS are the independent variables.

\begin{tabular}{|l|l|l|l|l|}
\hline Variable & Min. & Max. & Mean & St.Dev. \\
\hline ECO_DVLPMNT & 1142 & 27758 & 17446 & 7955.12 \\
\hline ACCOUNT & 21649801 & 40516422 & 30502039 & 6760425 \\
\hline BORROWINGS & 121843 & 246193 & 186458 & 44825.87 \\
\hline SAVINGS & 2134871 & 7298799 & 4447717 & 168330 \\
\hline
\end{tabular}

\subsection{Empirical Results}

Table 3 represents the results of our analysis where for the sake of brevity, variables have been presented in natural logarithm form of the original value. The first model, only SAVINGS and BORROWINGS variables have been considered. Whereas, in the second model, all the three variables ACCOUNT, SAVINGS and BORROWINGS have been considered simultaneously for analysis. Focusing on Model 2, our estimations support our Hypothesis 1 , as two out of the three selected variables have came up statistically significant when explaining inclusive development in Bangladesh. 
Table 3. Results

This table represents the results of the models of the effects of female financial inclusion on the inclusive economic development of Bangladesh. where ACCOUNT and SAVINGS variables are significant at $10 \%$ level of significance. Standard errors in parentheses. Significance levels $* * * p<0.01, * * p<0.05,{ }^{*} p<0.1$

\begin{tabular}{|l|l|l|}
\hline Variables & Model 1 & Model 2 \\
\hline ACCOUNT & & $6.8544^{*}$ \\
& & $(10.1376)$ \\
\hline BORROWINGS & 0.9831 & 2.2483 \\
& $(5.2740)$ & $(5.8013)$ \\
\hline SAVINGS & $2.1919^{*}$ & $0.8632^{*}$ \\
& $(3.2244)$ & $(5.6292)$ \\
\hline
\end{tabular}

Here, the final model indicates that, women of Bangladesh having accounts at a Bank (ACCOUNT) has positive correlation with the economic development of Bangladesh $(\mathrm{p}=.065)$. The results also indicate that, the variable SAVINGS is also positively correlated with the economic development $(p=.083)$. Moreover, we found that, the variable BORROWINGS indicating funds borrowed by women from a bank is not statistically significant even though it is showing positive relation. These results clearly indicate that, regarding female inclusion, bank accounts of women and savings of women with a bank is triggering higher economic development of Bangladesh but borrowings of women from a bank is not driving higher economic development of Bangladesh.

The results of our findings are in line with other previous studies (L. Cabeza-García et al., 2019, Pitt et al., 2006; Saroj \& Singh, 2015) suggesting a positive relation between the financial inclusion of women and economic development of a country. The main contribution of our paper is to focus our results on the financial inclusion of women in Bangladesh. From our analysis it can be concluded that female financial inclusion is positively correlated with economic development of Bangladesh.

\section{Discussion and Conclusion}

In this paper the authors have analyzed the effect of women participation in the financial system and it has been found that the participation of women in the financial system through the usage of financial services enhance the economic development of Bangladesh. In order to address this issue, we have considered three main aspects of female financial inclusion which are savings, access to bank borrowings and account with a bank. From our analysis we found that savings and access to a bank account have significant impact in triggering the higher inclusive economic development of Bangladesh. But the results of our analysis also indicate that borrowings of women from a bank is not driving the economic development of Bangladesh.

As mentioned earlier that, $51 \%$ of the population of Bangladesh is women and their engagement in the economy and financial system is essential for sustainable economic growth and development of the Bangladeshi economy. Bangladesh government has already taken several steps through Bangladesh Bank to ensure more participation of women in the financial system which has led Bangladesh as a role model for pioneering financial inclusion for women in the world. Participation of women in the financial system helps the women to become financially independent which ultimately assists in reducing poverty and vulnerability of women and helps in increasing productivity of the nation as a whole. Because women financial inclusion provides opportunity to the women to start their own venture which supports in increasing their standard of living and the living standard of the family as well. Also, financial inclusion promotes the employment of women, raises the self-esteem of women, and makes them into the agents of their own development which ultimately makes the economy more dynamic and creating employment (Kim, 2016). In the context of emerging economy like Bangladesh, it is necessary to ensure Women's access to safe and affordable financing and other financial services for accelerating economic development and growth, reducing income disparities and poverty.

We believe that our study fruitful from the perspective of both academic and policy making. The findings are helpful for policymakers in formulating policies regarding greater female financial inclusion. For future research, it could be interesting to analyze the factors determining female financial inclusion in Bangladesh. However, our study has some limitations and data constraint is significant among those. We were unable to employ more years of data. Also, there could have some other dimensions of female financial inclusion such as online payment by female, use of credit card but because of unavailability of data we could not consider those.

In this paper, we have tried to highlight the importance of reducing gender gap in financial inclusion. The government, policymakers and regulators and financial institutions of Bangladesh come forward and should work together to reduce the gender gap in financial inclusion in Bangladesh. Also, better policy should be introduced to enhance the economic development by empowering the women of Bangladesh.

\section{References}

Ahmed, N., (2020). Gender disparity in financial inclusion. [online] The Financial Express. Available at: $<$ https://today.thefinancialexpress.com.bd/27th-anniversary-issue-1/gender-disparity-in-financial-inclusion- 
1604921097> [Accessed 6 October 2021].

Aliance for Financial Inclusion (AFI), (2017). Expanding women's financial inclusion in Bangladesh through MSME finance policies. Case study no 5, page-3.

BBS. (2013). Gender statistics of Bangladesh 2012. Dhaka: Bangladesh Bureau of Statistics (BBS), Ministry of Planning, Government of Bangladesh.

CGAP. (2019). Could e-Commerce Bring Women's Financial Inclusion in Bangladesh? Retrieved from CGAP: https://www.cgap.org/blog/could-ecommerce- bring-womens-financial inclusion- Bangladesh.

Demirguc-Kunt, A., Klapper, L., \& Singer, D. (2013). Financial inclusion and legal discrimination against women. [Policy Research Working Paper No. 6416].

Global Impact Investing Network (GIIN), (2019). Available at https://navigatingimpact.thegiin.org/strat egy/gli/increasing-venture-capital-towomen- led-businesses. Accessed on 15 August 2021.

Greenspan, A. (2002). Financial Literacy: A Tool for Economic Progress. Futurist 36(4): 37-41.

Haque, H., (2021). Gender Equality and Women's Empowerment | Bangladesh | U.S. Agency for International Development. [online] Usaid.gov. Available at: <https://www.usaid.gov/bangladesh/gender-equality-andwomens-empowerment> [Accessed 7 October 2021].

The GSMA. (2019). The Mobile Gender Gap Report 2019. London: GSM Association.

The GSMA (2019) Digital identity opportunities for women Insights from Nigeria, Bangladesh, and Rwanda. London: GSM Association.

International Labour Office. (2006). Measuring gender dimensions of the world of work in Bangladesh: A training guide. Geneva: International Labour Organization (ILO).

International Monetary Fund (2018). Pursuing Women's Economic Empowerment https:/www.imf.org/en/Publications/Policy-Papers/Issues/2018/05/31/pp053118pursuing-w mens-economic-empowerment

International Centre for Research on Women (ICRW), (2010). Promoting effective investment in women's empowerment.Available:at:https://www.icrw.org/research-programs/promoting-effective-investment-inwomens-empowerment/ Retrived: 10/6/2021

Institute of Microfinance (InM), (2015). National convention on inclusive finance in Bangladesh. Page:15-17

Islam, M. Z. (2018, March 8). Women triumph in ecommerce. The Daily Star.

Kabeer, N. (2013). Paid work, women's empowerment and inclusive growth: Transforming the structures of constraint. New York: UN Women.

Kim, J. H. (2016). A study on the effect of financial inclusion on the relationship between income inequality and economic growth. Emerging Markets Finance \& Trade, 52, 498-512.

Khalily, M. A. B., and M. A. Khaleque. (2013). Access to Credit and Productivity of Enterprises in Bangladesh: Is There Causality? Working Paper 20. Dhaka: Institute of Microfinance.

Khalily, M. A. B., and P. Miah. (2015). Financial Literacy and Its Impact on Inclusive Finance in Bangladesh. Institute of Microfinance. Mimeo.

Khalily, M. A. B., and M. A. Khaleque. (2011). Access to Financial Services in Bangladesh. Institute of Microfinance. Mimeo.

Khalily, M. A. B., and P. Miah. (2015). Financial Literacy and Its Impact on Inclusive Finance in Bangladesh. Institute of Microfinance. Mimeo

Khatun, Fahmida; Khan, Towfiqul Islam; Tashfique, Kazi Golam. (2015). Estimating Unpaid Work in Bangladesh's GDP: A Conceptual Framework for Household Satellite Accounts Approach. (C) Centre for Policy Dialogue. http://hdl.handle.net/11540/12466.

Khatun, F., Khan, T., Pervin, S. and Jahan, H., (2015). Estimating women's contribution to the economy. Dhaka: Center for Policy Dialogue, pp.27-100.

Lagarde, C. (2014). Managing Director, International Monetary Fund. (I. F. Inclusion, Interviewer)

Miller, M., N. Godfrey, B. Levesque, and E. Stark, E. (2009). The Case for Financial Literacy in Developing Countries: Promoting Access to Finance by Empowering Consumers. World Bank, DFID, OECD, and CGAP.

Mohanty, B (1995).'Women and Political Empowerment', Proceedings of the Women's Political Empowerment Day celebrations, 23-24, April 1995, Institute of Social Sciences, New Delhi, India.

Rahman, KMM (2013), Demographic and Economic Profile of Women', in Titumir RAM (ed.), Institutions Matter: State of Women in Bangladesh 2013, Shrabon Prokashani, Dhaka, Bangladesh, pp. 15-34.

Cuberes, D., \& Teignier, M. (2016). Aggregate Effects of Gender Gaps in the Labor Market: A Quantitative Estimate. Journal of Human Capital, 10(1), 1-32.https://doi.org/10.1086/683847

Sen, G \& Batliwala S (2000), Women's Empowerment and Demographic Processes: Moving Beyond Cairo, in HB Presser and G Sen (eds), Oxford University Press, New York, pp. 95-118.

Siddik, M., (2017). Does Financial Inclusion Promote Women Empowerment? Evidence from Bangladesh. Applied Economics and Finance, 4(4), p.169.

Shirin, M (1995) Achievements of Women in Mixed Farming, Success Stories of Women in Agriculture: 
Proceedings of a National Workshop on Case Studies, BARC, Dhaka, pp. 25-33.

The Global Findex Database (2017). Measuring Financial Inclusion and the Fintech Revolution (English). Washington, D.C.: World Bank Group.

Thompson, L., \& Walker, A. J. (1995). The lace of feminism in family studies. Journal of Marriage and the Family, 57 (4), 847-865.

UNCDF-SHIFT. (2018). Landscape Assessment of Retail Micro-Merchants in Bangladesh. New York: UNCDF.

UNCDF, (2006). "Building Inclusive Financial Sectors for Development", http://www.uncdf.org/sites/default/files/Documents/bluebook_1.pdf

Wahid, N. (2020). Business Access by BKash and Women's Empowerment. (K. Rickard, Interviewer)

Wachira, M., (2019). Women's financial inclusion: The smart thing to do - The Good Feed. [online] The Good Feed. Available at: <http://blog.brac.net/womens-financial-inclusion-the-smart-thing-to-do/> [Accessed 6 October 2021].

The World Bank. (2019). Girls'education in Bangladesh: A promising journey. Retrieved from World Bank Blogs: https://blogs.worldbank.org/endpovertyin southasia/girls-education-bangladeshpromising- journey

The World Bank. (2020). Retrieved from The World Bank: https://databank.worldbank.org/source/jobs/Type/TABLE/preview/on

World Economic Forum. (2019). Global Gender Gap Report 2020. Geneva: World Economic Forum. 